\title{
放電現象を利用した絶縁性セラミックスの新加工法
}

\author{
福澤 康・谷 貴幸*・岩根英二*・毛利尚武** \\ 長岡技術科学大学機械系, 940-21 長岡市上富岡町 1603-1 \\ *長岡技術科学大学大学院, 940-21 長岡市上富岡町 1603-1 \\ **豊田工業大学機械システム工学科, 468 名古屋市天白区久方 2-12-1
}

\section{A New Machining Method for Insulating Ceramics with an Electrical Discharge Phenomenon}

\author{
Yasushi FUKUZAWA, Takayuki TANI*, Eiji IWANE* and Naotake MOHRI** \\ Department of Mechanical Engineering, Nagaoka University of Technology, 1603-1, Kamitomioka-cho, Nagaoka-shi 940-21 \\ *Department of Mechanical Engineering, Graduate School, Nagaoka University of Technology, \\ 1603-1, Kamitomioka-cho, Nagaoka-shi 940-21 \\ **Department of Mechanical Engineering System, Toyota Technological Institute, 2-12-1, Hisakata, Tenpaku-ku, Nagoya-shi 468
}

[Received October 13, 1994; Accepted July 6, 1995]

\begin{abstract}
As the electro discharge phenomena can only occur between electro conductive materials and electrodes, the insulating materials could not been machined by electrical discharge machining (EDM) method. In this report, the new machining system is proposed and the machining characteristics of Sialon insulating ceramics are discussed. It is clarified that the insulating ceramics are also able to be machined using the standard EDM technique with the adhesive metal plate and soft metal electrodes. It is accomplished by using one of the surface modification techniques for continuously making an electro conductive surface layer on the insulating surface.
\end{abstract}

Key-words : Electrical discharge machining, Insulating sialon ceramics, Machining condition, Surface modification, Machined powder

\section{1. 緒言}

一般にセラミックス材料は, 高強度, 耐熱性, 耐食性, 耐摩耗性等の機能性に優れているが，高硬度であることや 耐衝撃性や延性に欠けるため切断や複雑な最終形状への加 工がかなり困難である.このため加工の点からも応用範囲 が限られることもある. 切断加工や表面研磨等はダイヤモ ンド砥粒を用いても行えるが，加工時間が長く高価な研削 盤を使用することが必要である. 更に, 複雑な形状は, 機 械加工ではなく各種の near net shape 法により作製され ているが，その装置や手法の繁雑さを考えると，簡単な加 工手段の開発が必要である.このためレーザー, 超音波と いった特殊な装置が必要とされる方法が実施されてき た1),2).これに対して放電加工方法は, 導電性材料を用い るかぎりではこれらの需要に適した方法である. しかしな がら, 現在注目されている多くの構造性及び機能性セラ ミックスは, 絶縁性である.このため, これまでにも放電 加工機で絶縁体を加工する幾つかの方法が試みられてき た. 例えばガラスやサファイヤ等を電解水溶液中での放電
加工による微細穴加工や3),4), 酸素や水素が発生する放電 現象を応用したワイヤ放電加工機による電解水溶液中での 加工がある4). しかしながら, 厚さが数 $\mathrm{mm}$ 以上の絶縁体 の切断加工, 数 $\mathrm{mm}$ 径の穴を貫通させる加工及び複雑形 状加工等は, 困難な場合が多い。 また, 通常の放電加工機 を用いた方法としては, 被加工物であるセラミックス材料 表面を蒸着法などにより導電状態にして加工する方法があ る5). 著者らもこの方法を試みたが, 表面層が薄い場合に は，この層と電極間で放電は生じるが，いったん加工され てその層が絶縁体表面から剝離してしまうと, その後は放 電が発生しなくなり，ごく短い時間内で加工は停止した. このため加工できる深さは数百 $\mu \mathrm{m}$ 程度が限界であり，そ の面積も非常に小さいものであった. しかしながら，この ように絶縁物でも電気的手法により加工が全くできないわ けではないことが分かる，そこで本論文では，これまでほ とんど行われていない，形彫放電加工機による絶縁性セラ ミックス材料加工の可能性を調べることを目的としていく つかの新しい加工法を試みた6).

この結果, 放電加工中に連続的な導電膜形成現象が生じ ると, 加工は可能であることが判明したので, 本論文でこ の新手法の加工方法と特性について論ずる.

\section{2. 実験方法及び供試材}

\section{1 供 試 材}

本研究で加工に用いた絶縁性セラミックスは, 主に Sialon であり, 比較のため $\mathrm{Al}_{2} \mathrm{O}_{3}, \mathrm{ZrO}_{2}$ 及び市販の陶器等も 用いた．表 1 に供試材 Sialon の機械的特性及び物性值を 示す. 電気抵抗值は $2.5 \times 10^{16} \Omega \cdot \mathrm{cm}$ であり, 予備的に行っ た通常の加工油中での放電加工ではまったく加工できな かった．電極材料としては主に市販の $\phi 1 \mathrm{~mm}$ の銅線，穴 径を大きくする場合には $5 \mathrm{~mm}$ 径の銅線を用い，更に電 極材料による加工特性を調べるためタングステン $(\mathrm{W})$, アルミニウム $(\mathrm{Al})$ ，ニッケル $(\mathrm{Ni})$ 及びチタン $(\mathrm{Ti})$ の 電極材料も用いた。 また，切断加工の場合には厚さ 1 
Table 1. Physical Properties of Insulating Sialon Ceramics

\begin{tabular}{|l|l|}
\hline Density & 3.22 \\
\hline Hardness (Hv) & 1300 \\
\hline Toughness (K K IC) & $6 \mathrm{MPa} \sqrt{\mathrm{m}}$ \\
\hline Elastic (Young's Modulus) (E) & $290 \mathrm{GPa}$ \\
\hline Thermal Expansion Coefficient $(\alpha)$ & $3 \times 10^{6} / \mathrm{K}$ \\
\hline Specific Heat & $0.6 \mathrm{~J} / \mathrm{g} \cdot \mathrm{K}$ \\
\hline Thermal Conductivity $(\lambda)$ & $21 \mathrm{~W} / \mathrm{mK}$ \\
\hline Porosity & less than $0.6 \%$ \\
\hline Resistivity (R) & $2.5 \times 10^{16} \Omega \cdot \mathrm{cm}$ \\
\hline
\end{tabular}

$\mathrm{mm}$ ，被加工絶縁体と同じ幅の銅板を用いた。後述する本 方法の特徵であるセラミック表面に補助的に密着させる金 属板は，主に $\mathrm{Cu}$ を用い，一部比較のために二ッケル $(\mathrm{Ni})$ む用いた．この金属の厚さは 1 10 mmの間で変化させ た.

\section{2 放電加工法}

絶縁性セラミックスの加工は, 通常の形彫放電加工機に より加工油中で行った．図１に，放電加工機内の浴槽にお ける電極と被加工物試料設置の概念図を示す. 導電性材料 に抢ける通常の加工と異なる点は, 被加工物上に電極より も大きな金属板を密着させることにある.加工はこのまま の状態で金属板上方表面からセラミックスの深さ方向へ 行った．表 2 に本論文で行った放電加工条件を示す．放電 条件は，電極極性を（一）に，放電電流值（ $I_{\mathrm{p}}$ ）を $5 \sim 35$ $\mathrm{A}$ の間，放電パルス幅（持続時間， $\tau_{\mathrm{p}}$ ）は 2 1024 $\mu \mathrm{s}$ の 間で変化させた。またDuty Factor $\left(\tau_{\mathrm{p}} / \tau_{\mathrm{p}}+\tau_{\mathrm{r}}\right)$ は0.2 99.8\%の範囲で変化させた。ここで， $\tau_{\mathrm{r}}$ は休止時間である.

加工状態の調査は, 小型ビデオカメラ (CCD カメラ)

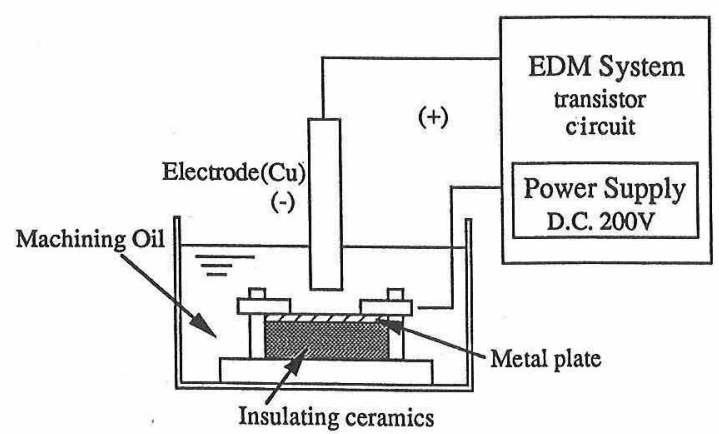

Fig. 1. Schematics illustrate of new EDM technique on insulating ceramics.

Table 2. Machining Conditions

\begin{tabular}{|l|c|}
\hline Peak current $\left(\mathrm{I}_{\mathrm{p}}\right)$ & $5,10,15,20,25,30,35(\mathrm{~A})$ \\
\hline Pulse duration $\left(\tau_{\mathrm{p}}\right)$ & $2,4,8,16,32,64,128,256,512,1024(\mu \mathrm{s})$ \\
\hline Electrode polarity & $(-)$ \\
\hline Atmosphere & Work oil \\
\hline
\end{tabular}

を用いた放電現象のその場観察，加工表面の粗さ，X 線 回折，X 線マイクロアナライザー (EPMA) 及び走査型 電子顕微鏡（SEM）による加工表面，断面観察により 行った。

\section{3. 実験結果及び考察}

\section{1 加工条件}

図 2 に Sialon の切断加工における放電発生状況を示す. ここで加工物は，加工油中にどぶ漬けしてある. 図は，1 $\mathrm{mm}$ 厚さの $\mathrm{Cu}$ 板を上部電極に用い，端部の電極先端々 Sialon 表面間で生じた放電を CCD カメラで観察した結果 である，導電性である上部金属の加工が終了しても，電極 材端部と Sialonの間で放電が継続して発生し，絶縁体が 加工されていることが観察できた．次に穴加工の可能性を 調べるため，上部金属に $5 \mathrm{~mm}$ 厚さの $\mathrm{Cu}$ 板を用いて，金 属板上部から密着した下部の Sialonの厚さ方向に，1 $\mathrm{mm}$ 径の $\mathrm{Cu}$ 線電極で加工した，上部金属板を貫通後更に セラミックス内へ $5 \mathrm{~min}$ 間穴加工した場合の加工表面及 び加工穴の縦断面とその加工穴表面粗さを図 3 (a), (b), (c)にそれぞれ示す。四3 (a)では，表面に電極径とほぼ 等しい円状の放電加工跡と周囲の豩離した形態を示す領域 及びその領域内に小数の微細渑裂が認められた。 また，図 3 (b)の縌断面図から，1 mm 程度の深さの穴が加工され， 加工痕表面には全体的に黒い生成物が付着していることが 観察できた。この断面写真において，表面近傍以外には目 視できる亀裂は観察されなかったので，図 3 (a)で観察さ れた刍裂は金属からセラミックスへと加工が変化する段階 で発生したと考えられる. 図 3 (c) の粗さ測定結果から分 かるように，加工表面全体は黒色生成物の付着物のため $R_{\max }=80 \mu \mathrm{m}$ 程度とかなり粗くなった。

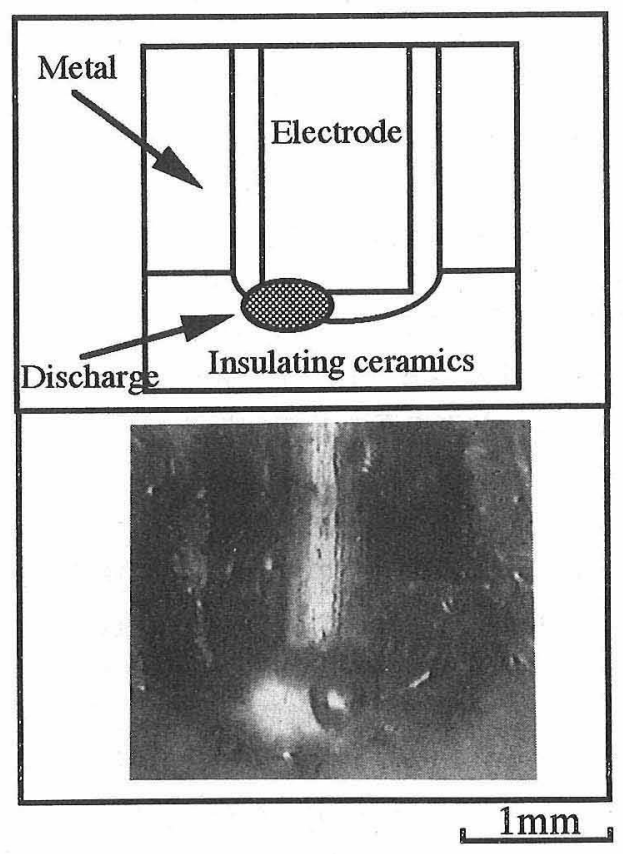

Fig. 2. Typical discharge behavior between insulating ceramics and electrode material in machining oil. 


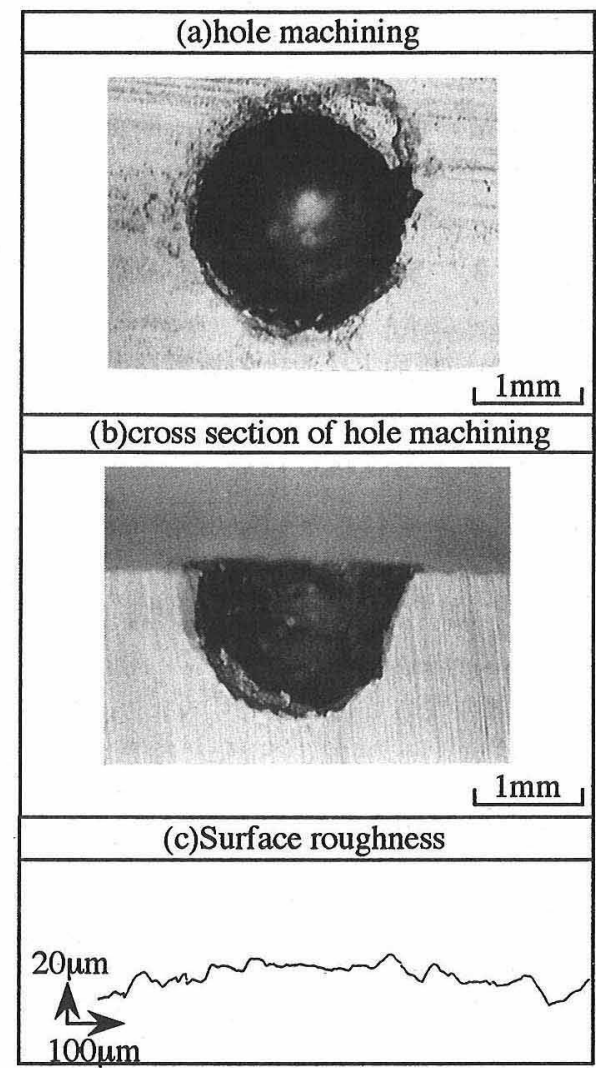

(I $=25 \mathrm{~A}, \tau \mathrm{p}=16 \mu \mathrm{s}, \mathrm{D} . \mathrm{F}=50 \%$,Electrode $\phi 1 \mathrm{~mm}$, Worked times 5min,Metal plate thickness $5 \mathrm{~mm}$ )

Fig. 3. SEM image of machined surface (a), cross section of machined surface (b), and surface roughness of machined surface for hole machined Sialon ceramics (c).

このように，超硬材等の導電性難加工材料の加工と同様 に，軟質金属である $\mathrm{Cu}$ 等の電極を用いて加工油中で，こ れまで不可能とされてきた絶縁性セラミックスの穴及び切 断加工が，著者らの提案する加工力法で放電加工が可能で あった．そこで，次に加工原理を明らかにするために， (1)加工面の表面状態と付着層の元素分析，(2) 電極材料 と加工速度との関係を調べた。電極材料には $\mathrm{W} ， \mathrm{Cu} ， \mathrm{Al}$, $\mathrm{Ni}$ 及び Ti の丸棒，上部金属材料としては $\mathrm{Cu}$ を用いた。 すべての加工は， $I_{\mathrm{p}}=25 \mathrm{~A}, \tau_{\mathrm{p}}=16 \mu \mathrm{s}$ の条件で実施した. 図 4 には $\mathrm{Cu}$ 電極一上部金属 $\mathrm{Cu}$ の組み合わせで $60 \mathrm{~s}$ 加工 表面の(a)SEM 観察及び(b)EDS 分析の結果を示す。ま た，図 5 には，加工表面の X 線回折結果を示す。図 4 (a) に示すように，加工表面には，導電性材料のような明確な 放電痕は認められないが, 微細な加工粉が全体に付着して いた. EDS 分析及びX線回折結果から，加工表面には， 電極又は上部金属成分からなる生成物及び被加工物と加工 油の熱分解によると考えられる炭化物 $(\alpha-\mathrm{SiC})$ と乱層カー ボンからなる表面層の存在が確認できた。 また，表面層の 電気抵抗は, $50 \sim 80 \Omega \cdot \mathrm{m}$ 程度の導電性を有し，黒色の部 分は機械的な手法により簡単に除去できた。 そこで電極材 料が加工状態に及ぼす影響を明らかにするために，W， Cu, $\mathrm{Al}, \mathrm{Ni}, \mathrm{Ti}$ を電極材料とし，各材料と加工速度との関係を

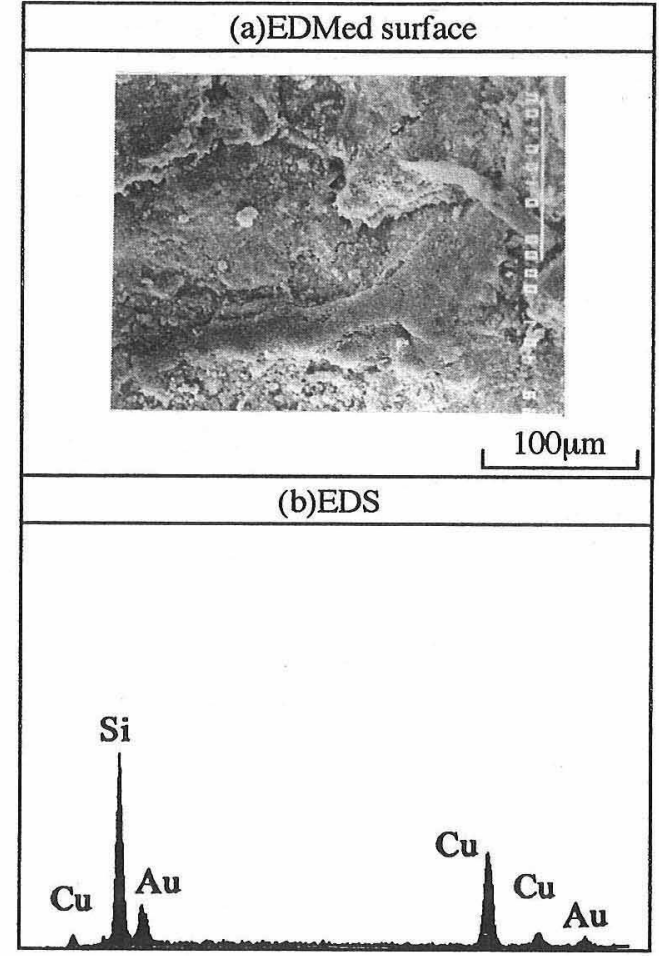

$(\mathrm{Ip}=25 \mathrm{~A}, \tau \mathrm{p}=16 \mu \mathrm{s}, \mathrm{D} . \mathrm{F}=50 \%$,Electrode $1 \mathrm{~mm}$, Worked times 5min,Metal plate thickness $5 \mathrm{~mm}$ )

Fig. 4. SEM micrographs of machined surface (a) and EDS analysis (b), for machined Sialon ceramics.

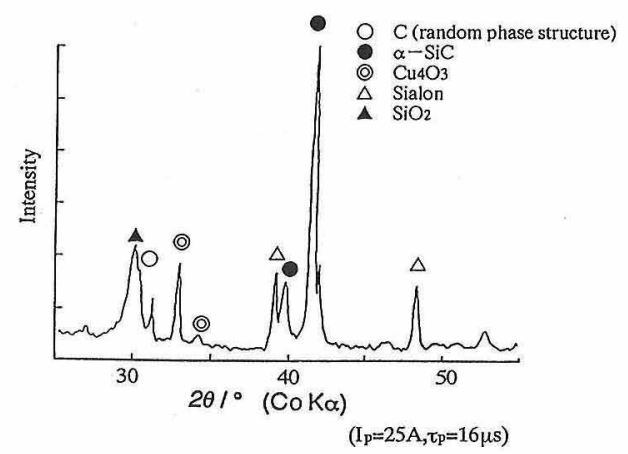

Fig. 5. XRD patterns of Machined Sialon surface.

調べた．上部金属材料には $5 \mathrm{~mm}$ 厚さの $\mathrm{Cu}$ を用いて，す べて同じ次の条件で加工した： $\tau_{\mathrm{p}}=16 \mu \mathrm{s}, I_{\mathrm{p}}=25 \mathrm{~A}$, Duty Factor $=50 \%$ ，加工時間 $\left(W_{\mathrm{t}}\right)=7 \mathrm{~min}$. 結果を図 6 に示 す. 加工速度は電極と上部金属材料が同一の $\mathrm{Cu}$ の場合が 最大となり， $\mathrm{Al}, \mathrm{Ni}, \mathrm{W}$ の順になった．電極材料の加工特 性の傾向を，融点，熱伝導率などの物理定数から放電工ネ ルギーを求めて関連づけることを試みたが，必ずしも一定 の関係を見いだすことはできなかった、いずれにしても本 実験の材料の組名合わせでは $\mathrm{Cu}-\mathrm{Cu}$ が最適であったの で，この材料組み合わせで加工条件による加工特性に及ぼ す影響を調べた。

既に述べたように，予備実験として行った蒸着膜のよう な薄い導電層との放電では，加工できる深さはごくわずか 


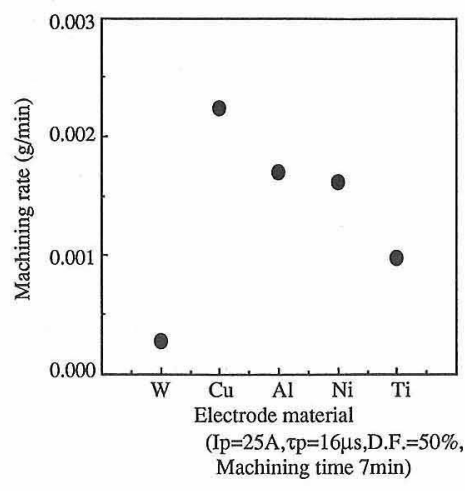

Fig. 6. Machining rate results of various electrode materials in the first machining stage.

であったので，本実験の手法においても限界加工量が上部 金属の厚さに依存する可能性があると予想した．そこで上 部金属の $\mathrm{Cu}$ 板の厚さを $1 \sim 10 \mathrm{~mm}$ まで变化させて, 1 $\mathrm{mm}$ 径の穴加工をした．その結果，上部金属板厚さにより 加工が進まなくなる限界深さが存在し，図７に示すように 板厚が $5 \mathrm{~mm}$ 以下の領域では, 加工限界深さは上部金属 厚さに依存し，板厚が $5 \mathrm{~mm}$ 以上となると加工深さは 5 $\mathrm{mm}$ を限界としてそれ以上の加工は不可能となった．図の 上部金属厚さと限界加工深さとの関係から，本論文で提唱 した加工方法を用いて, Sialon を穴加工する場合には, 上部金属が加工に寄与する厚さ（有効厚さ）が，加工限界 深さ $5 \mathrm{~mm}$ とほぼ一致することが分かった。 そこで，こ の加工限界は, 穴加工のみに存在するのか否かを検証する ため, 厚さ $1 \mathrm{~mm}$ ，長さ $30 \mathrm{~mm}$ の $\mathrm{Cu}$ 板を使用して同一の 方法で切断加工を試みた. 図 8 に10 mm 程度すでの樑さ まで加工した場合の切断面を示す. 加工条件は穴加工と同 じであるが，この場合には，穴加工のような限界值は本実 験の範团では存在せず更に深い加工ができ，現状では板厚 $20 \mathrm{~mm}$ 程度までの切断加工が可能である. 図 9 に穴加工 における上部金属板厚 $5 \mathrm{~mm}$ の場合の加工時間と加工深 さの関係を示す. 加工条件は図 7 と同じである. 加工深 さは加工開始直後は, $2 \mathrm{~mm}$ 程度まで数分で急速に加工で きたが，それ以後は加工速度は減少し, 加工限界値まで数 時間の加工時間を要した。加工限界深さを過ぎても放電現 象は継続するので，加工穴内部での放電状態は初期とは变 化し，導電層表面と電極間には，放電が発生するが，この 放電現象にはもはやセラミックスを加工する現象は存在し ていないと考えられる.

次に各電気条件と加工特性との関係を以下の項目につい て, $\mathrm{Cu}-\mathrm{Cu}$ の組み合わせの穴加工で調べた。(1)電流值： $I_{\mathrm{p}}$, (2)放電時間 : $\tau_{\mathrm{p}}$, (3)Duty Factor : D. F. と加工速度と

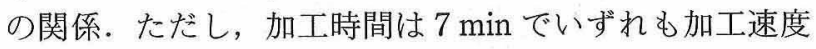
の早い領域である.

図10に電流值 $I_{\mathrm{p}}$ と加工速度の関係を示す．この場合に は25 A 程度で加工速度が極大となった． $\tau_{\mathrm{p}}$ 及び Duty Factor と加工速度との関係も調べた結果， $\tau_{\mathrm{p}}$ は $4 \mu \mathrm{s}$ と短い条 件で加工速度は最大となり, Duty Factor は，いずれの $\tau_{\mathrm{p}}$

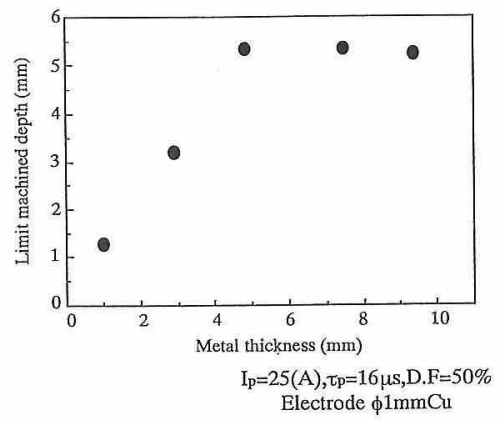

Fig. 7. Effects of the upper metal thickness for the limit machined depth on the Sialon ceramics.

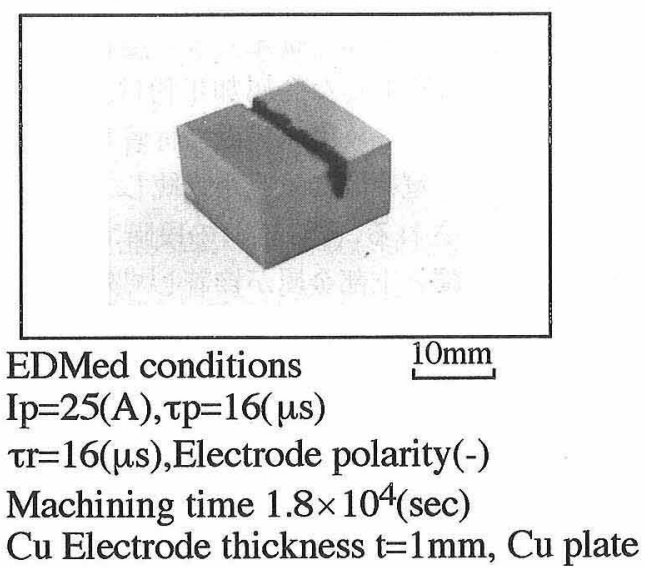

Fig. 8. Photograph of the cutting machined shape for Sialon ceramics.

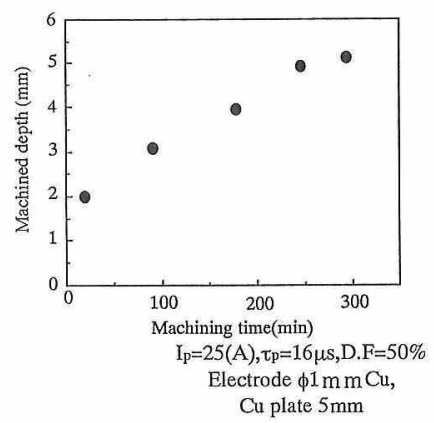

Fig. 9. Correlation between machined depth and worked time.

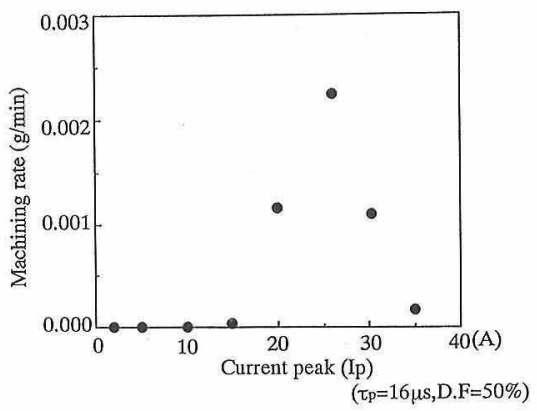

Fig. 10. Current peak $\left(I_{\mathrm{p}}\right)$ dependence of machining rate. 
の条件においてもD.F. $=50 \%$ が最大であった.この結果， 穴加工で加工物，電極及び上部金属の組み合わせを含み加 工速度を上昇させる最適の電気条件が存在することが分 かった。

\section{2 加工原理に関する考察}

図11k，これまでの実験結果から推定される加工過程の 概略を示す. 図11(a)は，通常の導電体金属の加工状態 で，セラミックス表面に近付いた状態を示す。（b）は，加 工初期の速度が速い状態，(c) は加工限界に達した状態を 示す。なた図12に図11の(b)，(c)に対応する底面での表面 層付着状態を示す. 図12から，加工速度が速い(a)の段階 では $100 \mu \mathrm{m}$ 程度なで形成されるのに対して，(b)の段階 では30 $\mu \mathrm{m}$ 程度むで減少した，以上の結果から加工過程 は次のように遷移していると推定している.

図11(a)で十分に発生した金属加工粉は，図11(b)に加 工が進むと瞬時にセラミックス表面に付着し薄い膜を形成 する：この表面層と電極間に放電が継続して発生すること により加工が継続される。図11(b)の段階では，加工穴全 体に付着した導電膜と上部金属が接着して外部と通電状態 になり，通常の導電性材料の放電加工と同様な加工が継続 するものと考えられる.

加工能力は，セラミックスが加工され新しい表面が形成 された後,この領域に適当な導電性を持つ膜が再び付着し なければ連続した加工はできなくなるので，生成物の成分 とその付着力に依存することになる．ここで，穴加工で加 工限界が生じる原因としては，加工粉が外部へ排出されや すいと考えられる切断加工では, 本実験の範囲内では加工 深さに限界が認められなかったことから，穴加工では剥離 した絶緑体セラミックスの加工粉が電極と被加工物との陌

(a)

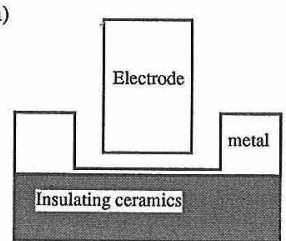

(b)

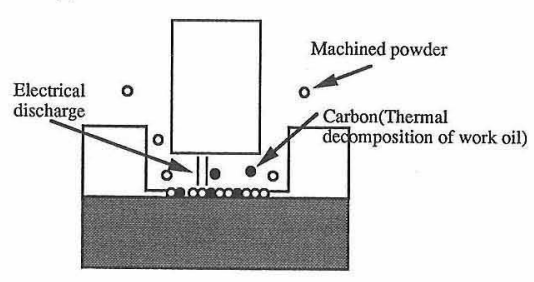

(c)

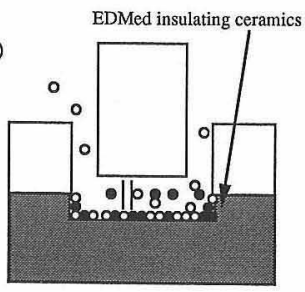

Fig. 11. Model of the EDM process for insulating ceramics on the new method.
間から十分に放出されなくなり，この隙間に充満して次第 に放電発生場所が減少して行く現象が考えられる。実際 に，加工限界深さに達した加工時間では，図13に示すよう に，1 mm 以上に成長した加工粉の塊の存在が確認でき た.ここで, 尊電性材料の加工に拉いても, 加工粉の排出 が不十分であると, 加工粉との放電集中により生成物が成 長して被加工物は加工されにくくなる傾向があるので7), 本方法においても，加工粉末の排出が加工限界に大きな影

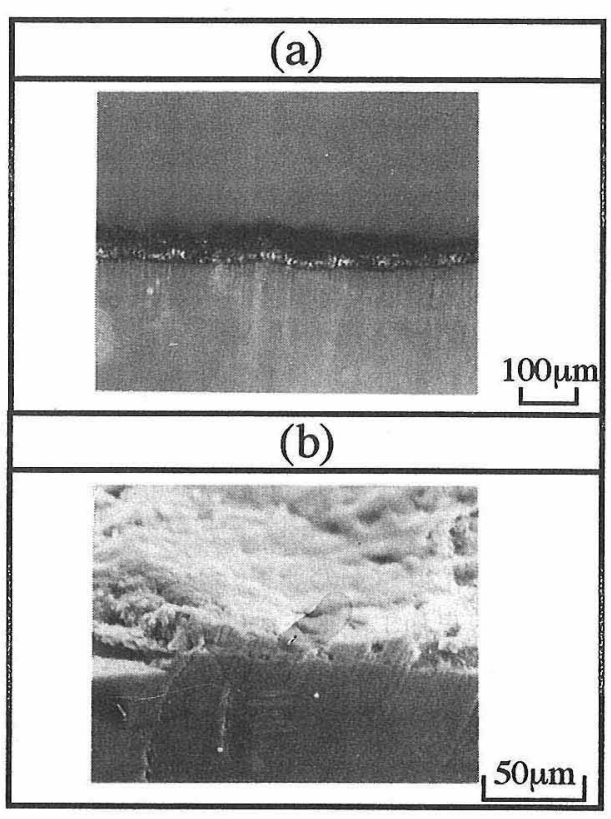

Fig. 12. SEM micrographs of machined surface profile. Figures (a) and (b) correspond to the machining stage of Figs. 11 (b) and (c), respectively.

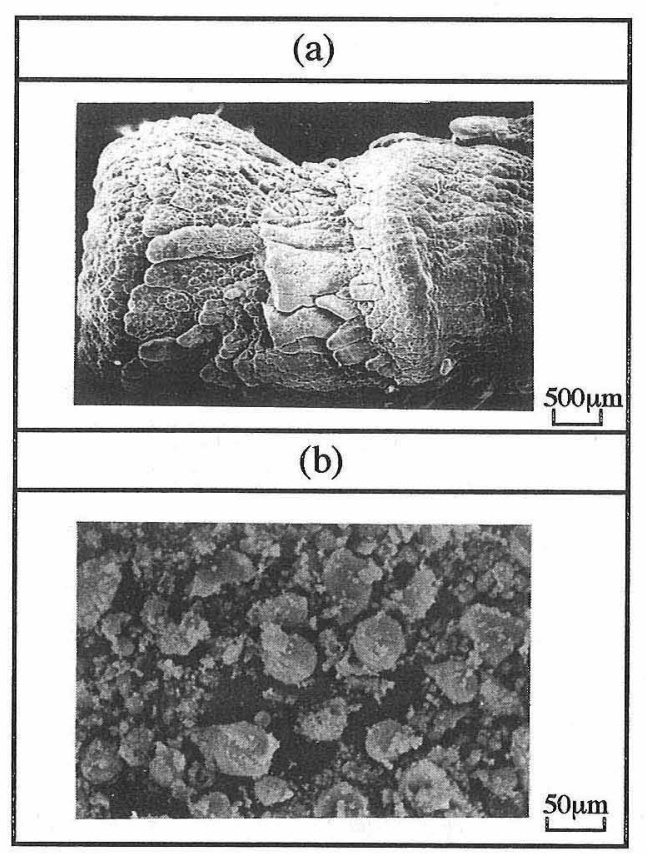

Fig. 13. Typical growing machined powder on the slow machining rate condition (a) and fast machining rate condition (b). 
響を与えている可能性は大きいと推定される.

図11(c)の領域では，図12に示したように加工層の厚さ は, 図11(b)のときよりも薄くなった. 次に, 図14に各加 工段階による電極消耗量の変化を示す. 図11(c)の段階で は電極の消耗がほぼなくなるので, 電極成分からの導電性 の加工粉の供給はなくなり, 新たに導電性の加工層を生成 させる現象はほとんどないと考えられる．この結果，極間 での放電は既に存在する導電性の加工膜を除去する放電と 累積した加工粉との放電だけとなり, 絶縁体の加工に寄与 する放電現象は，ほぼなくなったと考えられる．このほ か, 金属-絶縁性セラミックス接合体の界面近傍の加工に おいて, 導電性を有する界面から離れた所まで絶縁体表面 が加工可能であることから ${ }^{8)}$, 加工因子として絶縁体の表 面近傍にのみ流れる表皮電流効果も考慮する必要があると 思われる。

以上，述べてきた実験結果から，本方法は電極又は上部 金属の加工粉及び加工油の熱分解から生じる炭素成分から なる導電性を有する薄膜を絶縁体表面に連続的に付着させ るといった放電による表面改質 ${ }^{9)}$ を伴う加工方法であると 考えられる.

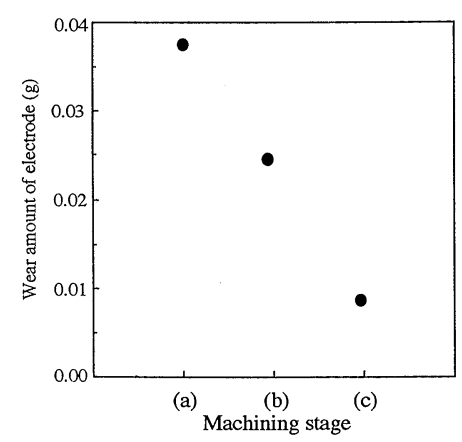

Fig. 14. Wear amount of electrode on each machining stage of Figs. 11 (a), (b) and (c).

\section{4. 結 言}

本論文では，従来不可能とされてきた絶縁体を，通常の 放電加工機で加工する方法を確立し, その性能と加工原理 について調査した．以下に結果を要約する.

（1）絶縁体セラミックス Sialon を，表面に導電体金属 板を密着させることにより，通常の放電加工機を用いて加 工できる方法を確立した。

（2）本実験の範囲では，穴加工においては深さ $5 \mathrm{~mm}$ 程度に加工限界が生じたが，切断加工では， $20 \mathrm{~mm}$ 程度 まで加工可能であった.

（3）上部金属の材質, 放電条件により，加工速度及び 加工表面状態が大きく変化した。

（4）加工された絶縁体表面には，加工により生成され た導電性膜の付着が確認できた。

\section{文献}

1）後藤英和, 土屋八郎, 片岡秀直, 電気加工学会誌, 25 , No. 50, 13-21 (1991).

2) 中村 守, 電気加工学会誌, 19, No. 37, 1-11 (1985).

3) 土屋八郎, 後藤英和, 宮崎 真, 井上友一, 電気加工学会誌, 20, No. 40, 24-31 (1987).

4）土屋八郎，後藤英和，宮崎 真，高田暢茂，小野 潔，電気 加工学会誌, 21, No. 41, 1-11 (1988).

5）二村昭二他，特許，昭和63年， 150109 .

6）福澤 康, 岩根英二, 毛利尚武, 第 3 回電気加工学会全国大 会講演論文集 (1993) pp. 63-66.

7）斎藤長男監修，“放電加工のしくみと $100 \%$ 活用法”，技術評 論社 (1979).

8）福澤 康，岩根英二，毛利尚武，まてりあ，33，823-25 (1994).

9) Y. Fukuzawa, Y. Kojima, E. Sekiguchi and N. Mohori, ISIJ International, 33, 996-1002 (1993). 